\title{
The Best of Both Worlds or the Worst of Both Worlds? Multilateral Development Banks, Immunities and Accountability to Rights-Holders
}

\author{
Gamze Erdem Türkelli ${ }^{1}$ D
}

Published online: 6 April 2020

(c) The Author(s) 2020

\begin{abstract}
Multilateral development banks (MDBs) are accorded immunities and privileges as agents of their member states as justified by functionalist arguments. They are also operationally hybrid: they are actors in their own right in addition to being functional agents. Navigating the functionalist imagery and relying on the argument that they are delegated purely economic pursuits (i.e. financing economic development), MDBs are able to eschew accountability to rights-holders that are affected by their decisions and operations. Although administrative law approaches have succeeded in increasing transparency, instilling self-regulatory frameworks and providing for independent review, the absence of external oversight of such review mechanisms and the broad immunities to suit enjoyed by MDBs have impeded true accountability to rights-holders. This article argues that, in so far as they engage in private sector financing operations, MDBs and their constituent arms share the form, function and relationships of an economic corporation to a large extent. Consequently, their immunities should be limited to render them bound-like ordinary corporations- by the domestic norms with respect to rule of law and human rights of the home and host countries in which they operate in order to make them accountable to rightsholders and to provide recourse for wrongdoings.
\end{abstract}

Keywords Multilateral development banks · MDBs · World Bank · Immunities · Corporations $\cdot$ Human rights $\cdot$ Rule of law

\footnotetext{
I am grateful to Wouter Vandenhole, Koen de Feyter, Nicola Jägers, Daniel D. Bradlow, David Kinley, Stef Vandengiste, Celine Tan, Olga Martin-Ortega and Radu Mares for their valuable guidance and insightful comments on the broader research project on "Non-State Economic Actors and Children's Rights" that informed the preliminary research for this article. That research project was funded under the DOCPRO scheme of the University of Antwerp Special Research Fund (Bijzondere Onderzoeks Fonds - BOF). This article, written during my mandate as a Post-Doctoral Fellow Fundamental Research of the Research Foundation Flanders (FWO) File Number: $12 \mathrm{Q} 1719 \mathrm{~N}$, draws on some arguments from that doctoral project. I am also indebted to the anonymous reviewers who provided useful suggestions on how the arguments contained in this article may be strengthened and focused. Any errors and omissions, of course, remain my own.
}

Extended author information available on the last page of the article 


\section{Introduction}

The Supreme Court of the United States (SCOTUS) made headlines in human rights and international law circles when it delivered its opinion in the Budha Ismail Jam et al. v. the International Finance Corporation (IFC) case on 27 February 2019. Earth Rights International (ERI) that represented the petitioners considered this "historic 7-1 decision" to mean that the IFC would no longer be considered "'above the law'." (ERI 2019) The case concerns the claims brought against the IFC for environmental pollution affecting air, water and land resources as well as affected peoples' livelihoods related to the construction of a coal-fired power plant in Gujarat, India. In its opinion, the SCOTUS answered the question of whether the IFC, the private sector lending arm of the World Bank Group (WBG), enjoyed virtually absolute immunity from suit in the United States under the International Organizations Immunities Act (IOIA). The case, however, is interesting not only from the perspective of IO immunities but also and particularly from the perspective of the legal identity of multilateral development banks (MDBs) as actors that can channel state-like and corporate-like attributes and what this hybrid existence means for human rights accountability.

The IFC had provided 450 million USD in loans to the project sponsor, the Coastal Gujarat Power Ltd. in 2008 for the construction of the Mundra Ultra Mega Power Project or Mundra UMPP. According to the loan agreement between the IFC and the company, the IFC could withdraw financial support from the project if the terms of the agreement were not respected. The petitioners, Jam et al., brought the case against the IFC in the US District Court for the District of Columbia in 2015 for "for negligence, negligent supervision, public nuisance, private nuisance, trespass, and breach of contract" based on IFC's own internal audit findings of the project's noncompliance with IFC-approved environmental and social action plans. (SCOTUS 2018, p. 7) IFC moved to have the case struck out alleging that US courts lacked subject matter jurisdiction, citing IFC's immunity status under US law.

Applying the D.C. Circuit precedent in Atkinson v.Inter-American Development Bank, 156 F. 3d 1335 (CADC 1998), the District Court held that the IFC was immune from suit under US law at the time that the IOIA was enacted, in 1945. While the SCOTUS did not address the specific merits of the case under consideration, it ruled in favour of the petitioners that the IFC did not enjoy absolute immunity from suit under US law as some of its activities may be considered commercial and thus not immune from suit. ${ }^{1}$

The IFC had objected to the limitations on its immunity, contending that the purpose of such immunity of IOs was to "allow such organizations to freely pursue the collective goals of member countries without undue interference from the courts of any one member country." (SCOTUS 2018, p. 8) The IFC had further contended

\footnotetext{
1 This was based on the comparison of the immunities enjoyed by international organisations in the US with those enjoyed by foreign states. Because the Foreign Sovereign Immunities Act (FSIA), adopted in 1977, included a commercial activity exception to immunities, the SCOTUS ruled that the IOIA of 1945 could similarly be concluded to include that exception.).
} 
that because "most or all of [the] core activities [of international development banks]" were conducted using "the tools of commerce," anything less than absolute immunity would result in opening the flood gates to litigation by foreign plaintiffs and result in hampering the work of the IFC and other MDBs. ${ }^{2}$ (SCOTUS 2018, p. 2) The SCOTUS contested the claims that all such activities would be considered commercial $^{3}$ (noting, for instance, that conditional loans to governments would not qualify as such) and pointed to additional requirements under the commercial activities exception for plaintiffs to be able to bring suit in US courts. What will surely follow in the case is an inspection of whether the suit fulfils other conditions laid out by the law to be admissible and if deemed admissible, an in-depth analysis into the commercial nature IFC's lending activities, specifically to the Coastal Gujarat Power Limited and its possible legal responsibility for alleged harms on petitioners. Of course, Jam et al. are hardly the only individuals around the globe adversely affected by the decisions and activities of MDBs. ${ }^{4}$ Reports of such adverse impacts of MDB activity on individuals and groups and their human rights abound.

Independent of the particular US legal context, the idea that particular IOs such as the IFC may be found to fall within the application of the commercial activity exception as affirmed by the SCOTUS in Jam et al. $v$. the IFC raises more fundamental questions linked to the 'hybrid legal identity' of MDBs as institutions in their own right. MDBs such as those under the WBG are considered international organizations (IO) under public international law, owing to their membership composed of states. Yet, MDBs have specific mandates, their own management structures besides and beyond state representatives, and operations that have rendered them distinct from their shareholders (Collins and White 2011). The functional imagery, which allows these institutions to claim extensive immunities, becomes a particularly important stumbling block to accountability when these institutions finance activities or implement projects with adverse consequences for rights-holders. Of course, adverse consequences for rights-holders are not limited to situations where MDBs finance projects sponsored by the private sector, namely their non-sovereign operations. The 2019 report of the UN Independent Expert on foreign debt, other financial obligations and human rights notes that International Financial Institutions

\footnotetext{
2 Multilateral development bank (MDB) is as a term that encompasses an institution with the mandate to promote economic development and that is established by a multilateral agreement of participating states. It is true that other terms, such as International Financial Institution (IFI) or Development Finance Institution (DFI), have been used by authors in literature. DFIs often refer to institutions that finance the private sector to which states make equity contributions and IFIs often refer to the broadest range of actors involved in macroeconomic development, including the International Monetary Fund (IMF), to which the arguments in this paper do not apply. For this reason, the paper uses the term MDB.

3 Commercial activities are defined as those "by which a private party engages in' trade or commerce" (SCOTUS 2019, p. 14).

4 There is also another ongoing case against the IFC in US District Court for the District of Columbia. This second case was filed on behalf of farmers in Honduras against the IFC and IFC Asset Management Company for extending financing to palm oil plantations of the Dinant Corporation, that is allegedly implicated in the violence in the Bajo Aguán valley, including "murders, torture, assault, battery, trespass, unjust enrichment and other acts of aggression" that also involved the company's private security forces. (Provost 2017).
} 
(IFIs) may be held legally responsible for complicity if they impose on countries economic reforms that violate human rights, in the context of their sovereign operations (UNGA 2019).

This article specifically focuses on non-sovereign operations of MDBs and makes the case that limiting the immunities of MDBs to allow for external oversight of their non-sovereign lending and activities is a relevant response to the lack of accountability to rights-holders that characterizes the MDB operational landscape. This article seeks to move beyond the traditional functionalist theories of MDBs as IOs that carry out functions delegated by states to argue for limiting the immunities they enjoy when they provide private financing and non-sovereign lending. In what follows, the article first surveys the functionalist approach to MDBs as IOs and the consequent privileges, including their immunities and calls into question the premise that MDBs are delegates of their member states given their increasing autonomy. The article then focuses on the implications of the functional imagery, and the 'delegate veil' ${ }^{5}$ it creates for accountability to rights-holders and rule of law, assessing whether it is the best of both worlds or the worst, for the organizations themselves on the one hand and rights-holders on the other. Finally, the article proposes lifting the 'delegate veil', in order to uncover the corporate-like attributes of MDBs in terms of form, function and relationships. In order to move beyond the specificities of US law, which allows for immunity to be limited in case of commercial activities by an IO, the article suggests that MDBs should be treated as 'corporate-like' actors with regards to their non-sovereign operations and consequently be subject to the reach of domestic law in places they operate and where they have their headquarters or managing bodies as well as external oversight, including judicial review.

\section{MDBs as State Delegates: Functionalism and Privileges}

\subsection{MDBs as IOs}

Public international law has traditionally classified MDBs simply as IOs, of which one broad definition is "intergovernmental organizations, created by states, usually by means of a treaty, in order to exercise a task or function that states themselves are unable or unwilling to perform." (Klabbers 2017a, p. 90) IOs have long been understood in functionalist terms focusing on a 'principal-agent' paradigm based on their being "functional entities, set up to perform specific tasks for the greater good of mankind and, as such, in need of legal protection." (Klabbers 2015, p. 11). MDBs,

\footnotetext{
5 The 'delegate veil' is a play on the 'corporate veil', which shields shareholders from being personally liable for the corporation's debts and other obligations. In this case, the 'delegate veil' shields the MDBs from being responsible as institutions/actors in their own rights for the impacts of their own activities, based on the claim that they are merely the functional delegates of their shareholders (which happen to be states).
} 
defined as IOs are routinely accepted as subjects of international law and as international legal persons. ${ }^{6}$

Public international law has not problematized the granting of privileges and immunities to IOs because they are considered functional delegates of states. As international legal persons in their own right, IOs were given state-like privileges and immunities precisely because the latter were considered an extension of states' conferral of certain powers to these institutions. "Present[ing] [IOs] as neutral and a-political, solely functional entities" that assist States in achieving 'the good life' by performing certain functions" is, in Klabbers' terms, the "genius of functionalism." (Klabbers 2015, p. 18). It followed that the law should facilitate the functioning of IOs, including through the extension of immunities and other privileges (Klabbers 2015).

\subsection{Immunities of MDBs and Their Competences}

The immunities enjoyed by MDBs are routinely set out in their constitutive agreements. ${ }^{7}$ The immunities at the institutional level include immunity from judicial proceedings, immunity of assets from search, requisition, confiscation, expropriation or any other form of seizure, inviolability of archives, immunities from taxation. Immunities usually also extend to natural persons involved in these institutions' operations including, for instance, "[a]ll governors, executive directors, alternates, officers and employees" who enjoy immunity "from legal process with respect to acts performed ... in their official capacity, ... from migration restriction, registration requirements and national service obligations" as well as from travel restrictions (IBRD 2012, Art. VII Sec. 8).

The immunity accorded to MDBs was often considered absolute immunity (Klabbers 2015). Even then, despite the broad expressions of immunity in founding agreements, the drafters had followed a model similar to commercial banks, allowing judicial proceedings to be brought against these institutions by private individuals, particularly as regards their commercial dealings. The scope of activities that may be challenged at courts of course differ depending on the institution. For instance, International Bank for Reconstruction and Development (IBRD) and IFC agreements broadly allow for judicial actions to be brought in "a court of competent jurisdiction" in countries where the institutions have offices, appointed agents "accepting service or notice of process" or have "issued or guaranteed securities." (IBRD 2012, Art. VII, Sec. 3; IFC 2012, Art. VI, Sec. 3). ${ }^{8}$ The Asian Development Bank (ADB) qualifies the exceptional permission for legal process "in cases arising

\footnotetext{
6 Their being considered subjects of international law and international legal persons rests, in what may be deemed a rather circular fashion, on the ICJ's Reparation Opinion of 1949 (McBeth 2009).

7 An immunity provision is included in the agreements establishing the International Bank of Reconstruction and Development (IBRD), Multilateral Investment Guarantee Agency (MIGA), International Finance Corporation (IFC), African Development Bank (AfDB), Asian Development Bank (ADB), New Development Bank (NDB), Asian Infrastructure Investment Bank (AIIB).

8 IBRD, Articles of Agreement, Article VII, Sect. 3, and IFC, Articles of Agreement, Article VI, Sect. 3.
} 
out of or in connection with the exercise of its powers to borrow money, to guarantee obligations, or to buy and sell or underwrite the sale of securities." (ADB 1965, Art. 50(1)) More restrictively, the Agreement Establishing the African Development Bank (AfDB) only allows for judicial proceedings "in cases arising out of the exercise of its borrowing powers." (AfDB 2016, Art. 52(1)) By measure of their limited immunity against judicial proceedings, MDBs may be distinguished from other entities under the legal heading of IOs: their immunity is absolute only visà-vis member states and limited in so far as they engage in commercial activities that may impact private individuals (IBRD 2012, Art. VII Sec. 3; IFC 2012, Art. VI Sec. 3; AfDB 2016, Art. 52(2); ADB 1965, Art. 50(2)) Prior to the SCOTUS' Jam et al. $v$. the IFC decision, however, courts in domestic jurisdictions had tended to follow the absolute immunity approach when applying it in practice. Yet, in the time that has elapsed since most MDBs were established, their operations that were once conceived as dealing directly only with borrower countries have expanded to bring them more and more in contact with rights-holders (Bradlow 2019). In the aftermath of Jam, it is likely that the practice of immunity will converge more closely with immunity as ascribed in the foundational documents of many MDBs.

Klabbers distinguishes the capacity of an IO and its competences. Accordingly, while IOs may have broad-ranging legal capacity to engage in various activities, their capacity is limited by their functional competences (Klabbers 2017a). This being said, many 'IOs', including MDBs, have been acquiring competences rendering de facto mandates broader and broader, leading to what may be called an everexpanding mission (Lawrence 2008). Over time, the ever-expanding mission may result in the inappropriateness of the mission for the purposes of the organization, the lack of resources to accomplish this expanding mission and issues linked to a lack of legitimacy to perform such mission (Einhorn 2001; Lawrence 2008).

\subsection{Limits of Functionalist Imagery: Complexity of Interactions and Increasing Autonomy}

Two distinct but interrelated processes expose the limits of functionalist imagery: the complexity of interactions that underpin the work of IOs as well as their increasing autonomy from their member states. These processes are perceptible with reference to IOs more generally but especially evident in case of MDBs. First, the functionalist focus on the "relationship between organizations and their members" has rendered it quasi-mute when confronted with "legal issues that could not be cast in terms of that relationship ... [including] organizational issues (such as staff relations, relations between organs) and, most prominently perhaps, to the situation of third parties." (Klabbers 2015, p. 11) While the relationship of various IOs with their members is set out in constitutive legal documents, the web of interactions surrounding these organisations were weaved through practice and are bound to be changing in response to an ever-changing social, political and economic global landscape. In the world of legal fiction surrounding functionalist approaches, IOs had specific relationships to their member states but not to third parties. As Klabbers highlights, this was particularly true of rights-holders who had not yet been brought 
into the purview of public international law given the absence of human rights conventions at the time (Klabbers 2017b). As such, the relationships to third parties which have evolved through practice are still not reflected in legal theories underlying institutional approaches. Second, the increasing autonomy of IOs from their member states is a well-documented and well-known phenomenon (Collins and White 2011; Klabbers 2017b). This increasing autonomy means that the institutions become actors in their own right and not just the vehicles to channel member state decisions, plans and projects.

In response to the inadequacies of construing IOs merely as agents of states that primarily have a relationship with the latter, a three-fold transformation is argued to be taking place in the law of IOs, by and large due to the recognition that third party claims against these organizations merit real attention: firstly, a relaxation of the immunity hitherto applied; secondly, the opening up of IO activity and decisions to judicial review in domestic or regional settings; and thirdly, a move towards more accountability and thus eventually, responsibility (Klabbers 2015). In this vein, Bradlow noted that broad functional immunity for IOs had lost its rationale even prior to the outcome of Jam et al. v. the IFC at SCOTUS because of the expanded "scope of their activities to include operations that involve exerting direct authority over and/ or directly impacting the lives of individual citizens and communities." (Bradlow 2017, p. 47) Consequently, IOs had ended up less accountable for human rights than states that had delegated specific functions to them, making it untenable for them to "credibly continue to advocate that their member states should respect human rights and practice good governance while they fail to respect their stakeholders' right of access to an effective remedy." (Bradlow 2017, p. 47) The corresponding conclusion is that "the doctrine of functional immunity needs updating" in line with the expansion of organizational competences (Bradlow 2017, p. 47) which is also essential for ensuring judicial review and accountability, the other two elements of the three-fold transformation. In this respect, different types of IOs in different operational fields may need to be inspected differently with respect to how the transformation should happen.

\section{Implications of the Functionalist Imagery for Accountability to Rights-Holders and for Rule of Law}

The functionalist imagery surrounding MDBs has allowed them to navigate the domestic and international human rights accountability terrain by deploying their IO status and the privileges they and their management enjoy. They have argued that their obligation of neutrality and legal status as operational vessels of their member states preclude them from assuming legal responsibility to rights-holders. In fact, in its brief to the SCOTUS in Jam et al. v. the IFC, the IFC's counsel argued that anything short of absolute immunity for the "IFC and other development institutions" was undesirable on account that "[t]he prospect of becoming enmeshed in contentious litigation threatening billions in damages would force IFC to reevaluate its operations and policies to minimize litigation risk-a perspective that would be inimical to its development mission" (IFC 2018, p. 18). Of course, the development 
mission assumed here is implicitly one that places economic growth above human rights concerns. The brief also included a rather unfortunate insinuation that, if permitted, plaintiffs filing cases against the IFC (and other IOs) would do so because of "a particularly attractive slate of characteristics: self-imposed, rigorous internal standards, deep pockets, and a jurisdictional hook to get their claims before a U.S. court" (IFC 2018, p. 17). The IFC was almost portrayed as a victim of its own success in carrying out its functional mission. The only reliable means to continue this mission was for it to enjoy absolute immunity to being held accountable over other concerns, such as impacts on human beings, communities and the environment, or so it went. The assumption that MDBs can operate beyond legal constraints simply because of their mandates requiring them to carry out global collective objectives linked to economic development is a considerable and unwarranted challenge to rule of law, particularly when analysing rule of law "as an instrument of legal and social justice" (Khan 2016, p. 223).

\subsection{MDBs and Rights-Holders: The Best of Both Worlds or the Worst of Both Worlds}

The functionalist imagery has largely allowed MDBs to escape duty-bearing for impacts of their activities, policies and decisions on human beings in two ways. Firstly, at the international level, MDBs have managed to avoid engaging with human rights as codified under international law and ratified by their member states as well as the host states in which they work by invoking their delegate veil. For one, MDBs can claim that their competences do not extend to human rights as they are not parties to human rights treaties internationally. In addition, MDBs have been allowed to utilize the political prohibition clauses in their constitutive agreements to buttress their claims of inability to take anything other than economic considerations into account (Cissé 2011). The rather stern conclusions of the Special Rapporteur on extreme poverty and human rights, Philip Alston, on human rights and the World Bank have taken issue with this approach by noting that it is "incoherent, counterproductive and unsustainable" and renders the institution "a human rightsfree zone" which "[i]n its operational policies, in particular, ... treats human rights more like an infectious disease than universal values and obligations" (UNGA 2015, para 68). Secondly, MDBs have enjoyed broad (and often unlimited) immunities at the domestic level, particularly in host states but also in states where they have their headquarters and regional offices. These immunities have shielded the institutions from the reach of external accountability mechanisms.

Resulting situation is rather peculiar. States, that are members of MDBs, are dutybearers under their domestic laws and international treaties to which they are party. Corporations, that undertake development projects with financing from MDBs, are subject to the domestic laws of host states as well as home state legislation aimed at regulating their conduct abroad, such as France's law on the duty of vigilance. Recent legal developments, such as the Canadian Supreme Court's ruling in Nevsun Resources Ltd. v. Araya, demonstrate that customary international law may also be successfully invoked as a basis for allegations of corporate liability for human rights 
violations abroad (Supreme Court of Canada 2020). In addition, scholars and civil society representatives have been arguing for the need to introduce legally binding rules to regulate corporate actors (Bilchitz 2016; Awori et al. 2018; Erdem Türkelli 2020; López Latorre 2020), including through the ongoing work on a legally binding instrument on business and human rights under the auspices of the UN Human Rights Council. As such, rights-holders may find political or legal avenues to hold states and corporations accountable (Bradlow 2016). The MDBs, which are made up of state shareholders and provide financing to various private corporations around the globe, have remained exempt from both domestic law as well as international legal obligations as regards human rights.

The MDB avoidance of direct engagement with human rights is long-standing and has been based either on the claim that MDB constituent documents do not explicitly mandate it to engage with the realm of human rights or to the famous political prohibition that is a hallmark of the IBRD Articles of Agreement, replicated by other MDB foundational documents (Palacio 2006; Sarfaty 2009). Yet, more than 2 decades ago, WB's then Senior Vice President and General Counsel Ibrahim I. Shihata recognized that the WB prohibition of intervention in the political affairs of a recipient country did not preclude it from "promot[ing] a broad array of economic, social and cultural human rights" (Shihata 1996, p. 388). There is a wealth of scholarship on enhancing MDB accountability by either focusing on their state members as human rights duty-bearers (McInerney-Lankford 2010; De Schutter et al. 2012) or the MDBs, directly. (Bradlow 1996; De Feyter 2002; Skogly 2003; McInerney-Lankford 2010; BIC 2013; Van Genugten 2015).

It is largely uncontested that human rights obligations of states as members of different IOs, including different MDBs, remain unaltered. In fact, almost all State members of any existing MDB (whether regional or global) have undertaken some treaty-based human rights obligations as parties to the various UN and regional human rights treaties. Yet, as McBeth has noted, these MDBs themselves "must [additionally] have independent legal obligations, since a number of functions are typically delegated to secretariats, panels or subcommittees and are therefore not the direct result of collective State action." (McBeth 2009, p. 67) MDB decisions and performance are still often only measured against their own self-regulatory norms, which fall short of providing comprehensive rights protections to persons affected by such decisions and performance. The situation might create a best of both world scenario for MDBs in continuing to function free from non-financial or non-economic considerations but it creates a worst of both worlds scenario for rights-holders.

\subsection{Attempts to Bring About Institutional Accountability}

Scholars have grappled with the issue of accountability to third parties for the decisions and operations of international financial institutions (IFIs) in the presence of extensive immunities. This has most notably led to proposals to apply of administrative law principles on a global scale to these institutions based on their 'administrative' attributes in carrying out specialised functions delegated by member states. (Kingsbury et al. 2005; Cassese 2005; Von Bogdandy et al. 2010; Kingsbury 2011; 
Bradlow 2011; Benvenisti 2014; Dann 2017) The basic tenet is this: in exchange for wide-reaching immunities in domestic settings, IFIs should put in place veritable alternatives to adjudicate and remedy third party claims against the organization (Kingsbury 2011; Martha 2011).

The extension of administrative law principles, or the birth and growth of Global Administrative Law (GAL), has undoubtfully contributed to enhancing institutional accountability of IFIs, in particular MDBs. Administrative standards as formalized in internal policies and procedures have led to making IFIs more 'responsible' in their decision-making due to the extension of procedural requirements and safeguards. The period between 1980s and 2010 saw the proliferation of such formal internal policies and procedures for the regulation of IFI decision-making and implementation vis-à-vis external stakeholders (Dann 2017). The most significant achievement of a GAL approach has arguably been enhanced transparency and internal review by IFIs, including in the way they disclose their operational procedures and policies. (Bradlow 2011) The introduction of internal review processes has included the establishment of grievance mechanisms, the so-called Independent Accountability Mechanisms (IAMs), within IFIs pioneered by the World Bank Inspection Panel in 1993 and eventually taken up by major IFIs across the board. The establishment of such complaints mechanisms has been credited with "strengthening the role of the individual, pushing forward an element of an international rule of law" (Dann 2017, p. 432).

The IAMs of WB and the regional MDBs such as the AfDB and the ADB, are only able to assess the performance of the institution's management against the benchmark of the given institution's operational policies and guidelines. The processes employed by many MDB IAMs are strikingly similar. These bodies receive complaints from complainants, acknowledge receipt, seek management response, conduct eligibility assessments, which may include a visit to the project location. Based on the result of the eligibility assessment, the IAM may recommend a compliance review/investigation (depending on the terminology used by the IAM). Of course, at this step, Board of Directors approval needs to be sought. The compliance review or investigation results in a report, to which the management responds by making recommendations. The report and the recommendations are then presented to the Board for consideration and made public after Board approval. In the case of most MDBs, there are no appeals procedures after the Board "the same body ... that approved the project at issue" finalises a decision. ${ }^{9}$ (Daniel et al. 2016, p. 60). Despite the similarities between the IAMs of most MDBs, the Office of the Compliance Advisor Ombudsman (CAO) [of the IFC and Multilateral Investment Guarantee Agency (MIGA)] presents another model. The Office undertakes three functions. Its ombudsman/dispute resolution role allows complainants to sit around the table with IFC management as well as project sponsors and to have access to alternative dispute resolution. It can provide guidance to the WB Group President and IFC and

\footnotetext{
9 The notable exception is the European Investment Bank (EIB), which is designed as an integral part of the European Union architecture and thus subject to review by the European Ombudsman like other European Union institutions (Daniel et al. 2016, p. 60).
} 
MIGA senior management on the institutions' performance in its advisor role, while its compliance function focuses on the performance of IFC and MIGA management at the project-level with regards to environmental and social due diligence (IFC/ MIGA CAO 2013). While these three functions are portrayed as equally accessible to rights-holders, civil society organisations reviewing CAO past performance found that in fact, accessing compliance review could be discretionary, as "in some cases in which problem-solving was unsuccessful, the CAO went on to determine that the grievances at issue were not of the type amenable to compliance review because, even though they related to the social impacts of an IFC-finance project, they were not of sufficient magnitude or severity" (Daniel et al. 2016, pp. 74-75).

Kingsbury had contended that "investigative mechanisms, especially those that produce detailed and reasoned reports made widely available under a principle of transparency, [were] more likely to be established or to operate effectively" if IFIs broadly enjoyed immunity from liability vis-à-vis third-party claims (particularly when these third parties are affected persons and not third parties in employment or business relationships with the IFIs) (Kingsbury 2011, p. 19). It is perhaps also true that these immunities have facilitated "the increased use of investigation, review, transparency ... within IFIs" (Kingsbury 2011, p. 19). The flipside is that far-reaching immunities shield IFIs from consequent liability for wrongdoing, even when wrongdoing is ascertained during an internal review and investigation. This has allowed, among other things, IFIs to adopt a "piecemeal approach of singling out and regulating certain issue areas (e.g. indigenous peoples, involuntary resettlement), rather than focusing on the category of 'affected group' per se" (Jokubauskaite 2020, p. 3). Thus, even when a formal practice of legality through procedural certainty and compliance is achieved, that practice has not automatically translated into enhanced accountability to affected rights-holders. Despite the improvements that have been made with regards to increasing institutional accountability through more detailed procedures, granting an institution the ability to single out which rights-holders are entitled to a transparent review of policies, decisions and operations affecting them without reference to international standards and without external oversight is one of the clear shortcomings of the administrative law approach to regulating MDBs. While

[c]omplainants are undoubtedly better off than they would be in the absence of any complaint procedure, as they often have nowhere else to turn to seek redress ... the outcome rarely provides adequate remedy for the harm that people and communities affected by development projects have experienced (Daniel et al. 2016, p. 14).

In fact, the promise of an administrative law approach to MDBs was to situate them on a par with public institutions. Yet, at the end of the day, administrative law entails a fail-safe: the application of rule of law back to public institutions automatically through external review and judicial oversight. In the case of MDBs, the broad immunities they enjoy_including immunity from legal proceedings - as a result prevent this analogy from being taken to the natural conclusion that external review 
and judicial oversight should occur when self-regulation fails to deliver accountability to affected persons. ${ }^{10}$

Unfortunately, the experience of the last three decades has shown that the increased use of these mechanisms and increased transparency around MDB operations have not always yielded change or translated into accountability for rightsholders affected by MDB decisions and operations. In fact, the review process of WB's operational policies with respect to environmental and social safeguards demonstrates that focusing solely on improving the constitutional architecture of the MDB itself leads to a scenario where nothing fundamentally changes, particularly with respect accountability to rights-holders. ${ }^{11}$ The introduction of the WB's new Environmental and Social Framework (ESF) has allowed some advances in formalizing consultation rights in response to involuntary resettlement or the rights of indigenous peoples - albeit with such rights being defined in a rather limited and often restrictive fashion. Yet, it has also displaced duties from the WB onto borrower countries. While the new Environmental and Social Policy (ESP), which outlines the duties of the WB itself, recognizes a due diligence requirement on the Bank to assess and monitor, it also muddles the chain of responsibility by introducing - in what follows - more detailed thematic standards that are said to be directly applicable to borrowers but not as such—at least explicitly — to the WB itself (Dann and Riegner 2019). In the same vein, the WB Bank Directive on Environmental and Social Directive for Investment Project Financing, adopted on 28 January 2020, limits WB responsibilities of due diligence "to assess[ing] whether the Project is capable of being developed and implemented in accordance with the ESSs" and whether borrower systems "are likely" to address risks and impacts (WB 2020, Section V.2). There are additional responsibilities of the WB to support the borrower in the implementation of ESF obligations such as consultations or grievance mechanisms, in the management of environmental and social risks and impacts, and to monitor the performance of the borrower (WB 2020, Section III.A.2) but no changes are foreseen in ensuring WB accountability to rights-holders for the impacts of the projects if due diligence fails, beyond the already-existent compliance review by the Inspection Panel.

In addition to modernizing the internal review mechanism procedures by allowing such mechanisms to impose obligatory measures on the management to induce compliance with findings and remedies, including compensation to affected persons, immunity should no longer be used to diffuse responsibility on the part of MDBs or

\footnotetext{
${ }^{10}$ In this respect, the administrative analogy is perhaps less fit for purpose for multilateral development banks or development finance institutions set up as international organizations and more to entities like the European Investment Bank (EIB), which is an institution within the European Union architecture that allows private parties, including rights-holders, to appeal EIB Complaints Mechanism decisions to the European Ombudsman.

11 The author participated in the European public consultations on the review of the World Bank Safeguard policies over 3 years (from 2013 to 2015) as an academic stakeholder where much farther reaching proposals were made in relation to accountability to rights-holders but the final document only invokes "directly applicable" obligations "under relevant international treaties and agreements" (WB 2015, ESS 1, para 26).
} 
to impede external oversight mechanisms that allow for liability claims from project-affected persons (Daniel et al. 2016).

\subsection{Lifting the Delegate Veil}

This article hypothesizes that one way to overcome the absence of external oversight for MDB decisions and action linked to non-sovereign lending and operations is to dispense of the legal fictions surrounding their functional purpose and the linked arguments on the necessity of far-reaching immunities to protect that purpose. For this reason, the paradigm of principal states and the MDB agent should be seen as what it has become: a delegate veil. The solution is then to lift the delegate veil and to recognize that MDBs, in so far as they operate within the dominant market rationale in backing private investment and finance in developing countries through non-sovereign lending and operations, operate similarly to private commercial interests and not as international public institutions to which domestic public institutions have delegated decision-making and implementation power to "provid[e] ... international public goods" (Martha 2011, p. 97) as has hitherto been assumed.

This article proposes that such an overture may be made through limiting MDB immunities and lead to the application of rule of law norms to MDBs for their activities in financing investment involving private companies and by opening up their institutional performance to external scrutiny in domestic jurisdictions, including through judicial review. Against the background of the predominant but increasingly insufficient imagery of MDBs as IOs closely linked to and wielded by states under traditional conceptions of public international law, this article focuses on their hybrid nature, highlighting not legal form but practical substance. While the membership - or rather, the shareholder status - of MDBs is composed of states, MDBs largely mirror economic corporations in form, functions and relationships. What follows is an attempt to substantiate the bases for the proposal to lift the delegation veil, by examining the corporate machinery at work with respect to form, function and relationships of MDBs. Based on the reality of how MDBs operate in real life, their mandates and immunities should be so interpreted to render them subject to external oversight through regular procedural and judicial mechanisms, similar to private commercial entities.

\section{MDBs, Their Corporate-Like Attributes and the Case for Limiting Their Immunities}

Bradlow has also noted that MDBs have a dual character: they are intergovernmental organizations created by States with a specific mandate and for a public purpose, and they are organizations performing financial transactions similar to market-based transactions, rendering them akin to private sector financial institutions (Bradlow 2010). In a complex configuration, states are formally members, have set up MDBs for the purpose of economic and commercial multilateral cooperation and are represented by Executive Directors on the institutions' Boards of Directors. Yet, that the 
role of Executive Directors is based on an 'inherent dichotomy' in that they are both State representatives and officers of the institutions themselves (Barros 2019). Nonetheless, member states may and do retain legislative oversight of their contribution to MDBs, including with regards to human rights implications of their cooperation in MDBs, even if this practice is not universal across the board (Barros 2019).

\subsection{Corporate-Like Attributes of MDBs}

There are two reasons why the traditional characterization of MDBs simply as IOs is unsatisfactory. Firstly, the category of IOs is broad-brush. The United Nations (UN) and its affiliated institutions, the Council of Europe (CoE), the World Bank (WB), the World Trade Organization (WTO), the Organization of Economic Cooperation and Development (OECD), Association of Southeast Asian Nations (ASEAN) are all IOs. Yet, there is great variation between these institutions as regards their mandates, sectors of activity, operational competences, the level of autonomy they enjoy from their member states in decision-making and implementation as well as their impacts on third parties such as individuals or groups who are rights-holders. Secondly and more fundamentally, categorizing MDBs as IOs masks their hybrid nature that combines elements of the corporate form with intergovernmental structures. This hybrid nature is, in fact, the very tool through which MDBs are able to bypass external accountability: by focusing on their economic mandates or corporate functions to distance themselves from what they view as 'political' issues internationally and by focusing on their state links to distance themselves of accountability for their impacts domestically, through defending their immunities and privileges.

It may seem incongruous at first glance to argue that MDBs have corporate-like attributes $^{12}$ when literature on public international law suggests, if anything, that they are State-like. ${ }^{13}$ There are, however, very good reasons for doing so. Firstly, although their shareholders are states and their Boards of Directors represent a geographical composition of states, MDBs are more than simple instruments of their shareholding states and thus, actors in their own right. Secondly, because MDBs are specialized economic institutions, their modus operandi is more closely linked to that of corporations. They employ professional staff and focus on corporate-like performance in carrying out their daily operations. Thirdly, corporate actors and MDBs are linked in the way they operate on the ground, in that they are often found to be collaborating in financing relationships either directly or through intermediaries. As such, businesses and MDBs have composite or collective impacts that are not readily dissectible.

\footnotetext{
12 It has elsewhere been argued that the WB should be considered on a par with business enterprises and not states with regards to its relationship to the UN Guiding Principles on Business and Human Rights, based on the premises that it lacks territorial sovereignty, is reined by the political prohibition and is profit-seeking although it demonstrates State-like qualities of immunity and is controlled by states (Natenson 2015).

13 This is based on the functionalist idea outlined above that IOs are agents of states (principals) and are therefore entitled to an extension of State-like powers, privileges and immunities.
} 


\subsubsection{Form: Actors in Their Own Right}

Fully appreciating the 'corporate-like' attributes of MDBs first requires dissecting the corporation as a form. The critical appraisal of what the corporate form entails will allow situating MDBs in relation to the corporate form and to flesh out their 'corporate-like' attributes and functions.

The notion of the 'corporation' is a protean one, largely dependent on the disciplinary lens through which the object is viewed. For almost half a century now, the discipline of sociology has viewed the corporation as an institution made up constituent elements (whether these elements are individual persons, states or others) (Coleman 1974). Accordingly, the corporate actor has two essential features: the constituent elements of the corporate actor are "not substitutable for it as an actor" and the actor is structurally composed of positions even if these positions may be occupied by persons (or constituent elements) (Coleman 1992). In fact, the rise of the 'corporate actor' alongside natural persons on the social plane has been hailed as a great modern transformation, based on law's pivotal recognition of the corporate actor as a separate entity (Coleman 1990).

The economic corporation is the expression par excellence of the idea of the social corporate actor (Coleman 1992) and has since become the archetypical institution populating the economic landscape in producing systemic economic outcomes. The economic corporate form exists at the intersection of three disciplinary universes: law, economics and politics. An exploration into the corporate form by Veldman and Willmott from a management studies angle discerns three imaginaries of the corporation corresponding with these three disciplines. The legal imaginary centres on the idea of the corporation as a separate entity that is not as such 'owned' by its shareholders and that has stakeholders besides and beyond those shareholders. The economic imaginary, on the other hand, prioritizes the corporation's vocation as a nexus of contracts, the most important of which is the one between shareholders and management, therefore effectively excluding other possible stakeholders (Veldman and Willmott 2013). In the political imaginary, the modern corporation is considered to have evolved through "shifts in power relations between classes, and their respective capacities for mobilizing resources to consolidate or transform relations of domination." (Veldman and Willmott 2013, pp. 610-615). Accordingly, banking on limited liability, the newly emerging rentier class was able to secure dividends from investing in corporations "without the demands, costs, risks, or responsibilities [associated with economic partnerships] of overseeing, or even inquiring into, how their gains were generated." (Veldman and Willmott 2013, p. 613). These three imaginaries are seen as distinct, at times conflicting but ultimately interactive, each reaffirming the dominant market fundamentalist conceptualization of the primacy of shareholder value and of the importance of shareholder control. In sum, Veldman and Willmott sketch out the modern corporation as the particular expression of the zeitgeist of free market pre-eminence, where the identity of a separate entity is pitted against the primacy of shareholder interests that is further supported by advantages offered by limited liability (Veldman and Willmott 2013). In line with many economists, Veldman and Willmott view limited liability, the premise that shareholders 
have limited liability commensurate with their investment in an economic enterprise, as an essential element of the corporate form. ${ }^{14}$

Limited liability is but one attribute of the modern corporation. In his entry on "Corporations" in The Concise Encyclopedia of Economics, Robert Hessen, a renowned historian of business, writes that "a corporation should be defined as a legal and contractual mechanism for creating and operating a business for profit, using capital from investors that will be managed on their behalf by directors and officers." (Hessen 2007). To put it more simply, the corporation is a distinctive form of economic enterprise because "investment and management are split into two functions." (Hessen 2007). Because those owning the assets (shareholders) and those operating them (managers) are distinct, corporations exist as entities in their own right separate from their shareholders. In addition, other common features ascribed to the corporation are overlapping: perpetual life, separate entity based on hierarchy of authority and to an extent, limited liability, in addition of course to the ability to make profits or create economic value (Pilon 1979).

The following analysis appraising the attributes of MDBs against the parameters of the economic corporation (limited liability, value generating, perpetual life, separate entity based on hierarchy of authority) clearly uncovers important areas of overlap.

\section{Limited Liability}

Limited liability is a standard feature of the agreements establishing MDBs. IBRD Articles of Agreement note that "[1]iability on shares shall be limited to the unpaid portion of the issue price of the shares," a provision that is also featured in the agreements establishing the ADB and the AfDB as well as the newest MDBs, such as the New Development Bank (NDB) and the Asian Infrastructure Investment Bank (AIIB) (IBRD 2012, Art. II Sec. 6) IDA and IFC's agreements of establishment contain an identical provision on the limitation of liability: "No member shall be liable, by reason of its membership, for the obligations of the [Association/Corporation respectively]." (IDA 1960, Art. II Sec. 3; IFC 2012, Art. II Sec. 4)

\section{Value Generation}

Many MDBs have been set up to enable the financing they provide to generate returns on investment. Unlike most corporations, however, profit maximization is not a goal, even if it is considered desirable. For instance, although the WB does not aim to maximize profits, as would a corporation, its Treasury recognizes the WB as a profitable entity with an accent on "strong financial performance" to drive sustainable development. (WB Treasury n.d.) Profitability or economic value generation also becomes important as investment rating agencies such as Moody's, Fitch, and

\footnotetext{
14 An online encyclopedia of investment, Investopedia, defines a corporation in the following manner: "A corporation is a legal entity that is separate and distinct from its owners. ... While its exact legal status varies somewhat from jurisdiction to jurisdiction, the most important aspect of a corporation is limited liability. This means that shareholders have the right to participate in the profits, through dividends and/or the appreciation of stock, but are not held personally liable for the company's debts (Investopedia 2019).
} 
Standard and Poor's rate the corporate performance of MDBs for existing and prospective investors. While MDBs generate consistent returns on their investments, the profits they make are not routinely distributed to shareholders ${ }^{15}$ but returned to their equity pool to increase reserves or to fund other initiatives.

\section{Perpetual Life}

The multilateral agreements establishing MDBs implicitly anticipate perpetual life for the institutions, as there are contractually no terms foreseen for the automatic termination of their activities. This being said, the founding agreements do envisage scenarios of suspension (permanent or temporary) or termination of the institutions' operations. According to these scenarios, much like the corporate form, the MDB may suspend or terminate its operations by a decision of its Board of Governors (IBRD 2012; IDA 1960; IFC 2012; AfDB 2016; ADB 1965; NDB 2015; AIIB 2015). ${ }^{16}$

\section{Separate Entity Status and Hierarchical Authority}

The separate entity status for the corporation is accorded in domestic law as legal personality. This is one of the most contentious aspects when likening an MDB to a corporate actor because the recognition of the corporation as a person under international law is less straightforward. In addition, being likened to a corporate actor would detract from the status that MDBs enjoy under international law when defined simply as IOs.

The hierarchy of authority in the corporate form dictates a vertical organization with shareholders at the top and directors, management and other staff further down. In the corporate form, shareholders choose the Board of Directors, and Directors in turn choose the officers that manage the institution's daily affairs. MDBs largely follow the same corporate form and template. Member states choose Governors, which make up the Board of Governors; this Board delegates authority to Executive Directors that are eventually "responsible for the conduct of the general operations" of the institution, selecting a President and the staff responsible for operations (IBRD 2012, Art. V). Baimu and Panou point out the "corporate structure of the [WB], which, like other corporations, comprises shareholders whose interests are represented by a Board of Governors and a Board of Executive Directors" where "executive directors exercise both executive and oversight powers over the Bank" while the ultimate control is in the hands of shareholders (Baimu and Panou 2012, p. 150 [emphasis added; footnotes omitted]).

\footnotetext{
15 Nonetheless, many MDBs include the theoretical possibility of allocating dividends on returns to members in their foundational agreements.

${ }^{16}$ Agreements establishing the World Bank Group refer to permanent suspension of operations. In the case of the IBRD, IDA and IFC, Executive Directors may also take the decision to temporarily suspend operations in case of an emergency.
} 
The functional independence of the President, officers and staff of MDBs is recognized at least nominally by the agreements establishing them. The IBRD's Articles of Agreement, for instance, state that these individuals "owe their duty entirely to the Bank and to no other authority" and that member states "shall respect the international character of this duty and shall refrain from all attempts to influence any of them in the discharge of their duties." (IBRD 2012, Art. V Sec. 5(c)). The same provision is found in the foundational agreements of other MDBs such as the IFC, IDA, AfDB, ADB, AIIB and NDB. ${ }^{17}$ Thus, at least theoretically under the legal imaginary, the management and staff of these institutions are both independent of the shareholders and accountable to the institution itself. In practice, however, the functional independence argument may need to be qualified in two ways: the influence that management may have over the representatives of the shareholders (thus, the Board), and the direct or indirect influence that the shareholders wield on management. The two aspects of influence are not antithetical; in fact, they might be mutually reinforcing in that management and the major shareholders dominate institutional decision-making structures at the expense of other shareholders.

The World Bank (WB), as the first MDB and the original type after which all other institutions of similar nature were modelled, has been the primary nexus of inquiry as regards the relationship between shareholders and management. Accordingly, it has been argued that the division of labour between ownership and management at the WB means not only that management has nominal functional independence but also that there might be a dependency relationship between the management and the Board. Woods concluded in 2003 that the WB suffered from governance and accountability deficits linked notably to the relationship between the management and staff, and the shareholder states. This was because the Board itself was "not independent of the staff and management":

Executive-directors are paid by and housed within each institution and have a dual role as officials of the organization as well as representatives of countries; many flit from Board to staff and back again. ... [F]ew have the advantage of resources and staff working on Fund and Bank issues in their constituency countries. Furthermore, when proposals come before the Board, executivedirectors are not privy to the disagreements and alternatives that have been debated among staff and senior management. The latter present just one proposal to the Board, leaving executive-directors either to accept or to reject. Finetuning is seldom entertained (Woods 2003).

This is the background to WB critics' claim that, having delegated a wide range of functions to the Executive Directors, the Board is a rubber-stamping body for the management, which is already plagued by a culture of loan approval. (Rich 2002).

The formal and informal influence of bigger shareholders in the decision-making processes of MDBs such as the WB and the ADB, and the instrumentalization by these shareholders of MDBs provided by these institutions to promote foreign

\footnotetext{
17 In institutions that constitute a part of the WBG, the functional independence of the management is established under the provisions on the President and Staff.
} 
policy objectives have been well-documented (Barnebeck et al. 2006; Kilby 2006, 2009, 2013; Dreher et al. 2009) Most of the attention with respect to the exercise of influence has centred on the US as the major shareholder of Bretton Woods Institutions. ${ }^{18}$ Yet, empirical evidence suggests that the influence of major shareholders in MDBs may be less uniform than anticipated, at least in the case of the Bretton Woods Institutions. ${ }^{19}$

A 2016 study by Kersting and Kilby explored the influence of domestic politics in US activities within the WB, and found that "previous U.S. influence in MDBs is largely driven by periods of divided U.S. government" where the Presidency and the Congress are held by different parties. (Kersting and Kilby 2016, p. 4) Looking at enforcement of conditionality, speed of loan disbursement, project ratings and electioneering (the disbursement of WB financial assistance to borrower countries aligned with US policies prior to elections), the authors found that US Presidents may choose to work through multilateral organizations to achieve policy objectives when they are unable to do so through bilateral action due to the Congress being controlled by the opposition (Kersting and Kilby 2016). Elsewhere, Daugirdas argues that the US Congress not only "put[s] the brakes on executive branch policies with which it disagrees; it affirmatively shapes the policies that the executive branch pursues." (Daugirdas 2013, p. 561). In fact, in the competition between the executive and legislative branches of US government, US Congress actions are argued to have "led the Bank's other member states, as well as its management and staff, to complain bitterly about U.S. actions that have unnecessarily polarized and politicized the Bank's work and undermined its international character." (Daugirdas 2013, p. 562). These studies clearly show that states seek to achieve particular policy objectives in development finance they provide, irrespective of the channel through which they do so. They also show that MDB management might not be completely satisfied with being a functional delegate of one of its member states. Another implication is that domestic politics may dictate whether or not a major shareholder State utilizes its influence in a given situation and how much influence it exerts.

It has also been argued that the WB's management being dominated by individuals from the economics disciplinary background has rendered the institution less open to comprehensively engaging with non-economic concerns, such as human rights, as the rights parlance is often viewed as a competing discourse to economic development (Sarfaty 2012). This argument, coupled with the economic imaginary of the corporation as elucidated by Veldman and Willmott that puts an accent on creating value for shareholders, may be a plausible explanation of why donor countries are able to exert informal influence in WB decisions through the staff's automatic anticipation of the importance donor countries attribute to certain borrower countries based on the political conjuncture (Dreher et al. 2009). ${ }^{20}$

\footnotetext{
${ }_{18}$ With the exception of Kilby's work on the Asian Development Bank and the role of Japan therein.

${ }^{19}$ It remains to be seen how the BRICS and China will engage with the NDB and AIIB as major shareholders.

${ }^{20}$ Dreher, Sturm and Vreeland note, for instance, that in line with major donor countries' desire to align the positions of temporary UN Security Council (UNSC) members with their own positions in the Secu-
} 
While the separate identity of MDBs is not in question, the hierarchy of authority and the functional independence of them as actors may be called into question in practice. In this respect, it should be noted that MDBs do not conform to the ideal corporate form.

\subsubsection{Function: Corporate Modus Operandi}

Further to corporate-like attributes in form, the way of that operations of MDBs are run, the discourse that is used in communicating internally and externally, and the parameters for evaluating performance are all indicative of a corporate modus operandi.

\section{Operations}

MDB operations are organized in a corporate-like fashion, from their management of programs and projects in line with institutional strategies and priorities to how their institutional culture is fostered, including through the recruitment and training of staff. The economic operations of many MDBs follow a business model that "rel[ies] on access to relatively cheap financing from capital markets" in return for bonds and investment products they issue, and this financing is then extended as loans to borrowers (or clients, based on the terminology used by the institutions themselves) (Baimu and Panou 2012, p. 151). ${ }^{21}$ In addition, in line with a corporate mode of operating, MDBs are often found to "compete for business on price and product among their client countries." (Zimmermann and Fariello, Jr. 2012, p. 191).

The lending, at least theoretically, follows the strategic developmental priorities of each institution. This being said, developmental priorities such as gender may not trickle down to operations, especially if they are not self-evident in the overall corporate vision of the institution "perceived as reflecting more 'real' corporate priorities" such as good governance and are not backed by top-down implementation (IEG 2012, pp. 30-31).

Even if MDBs are not profit-maximizing entities, corporate performance indicators such as profitability and lending volume may dominate performance metrics. In this regard, the IFC Management's response to the 2016 Evaluation of the WB by the IEG is telling. The IFC staff responding to the FY16 Survey noted that the management considered "volume targets and project profitability to be the most important metrics" while the management asserted that other priorities "such as development impact and client satisfaction" were also notable (IEG 2017, p. xix). In fact, the IFC Management is essentially conceding the corporate-driven nature of IFC operations,

\footnotetext{
Footnote 20 (continued)

rity Council, WB staff "may recognize the importance of a temporary [UNSC] member and expedite the request so that it reaches the Executive Board faster" (Dreher et al. 2009, p. 4).

21 One notable exception is the IDA, which is dependent on replenishments as it is a highly concessional lending institution.
} 
in putting an accent on volume targets, profitability and client satisfaction alongside development impact, seeing as the institution was established " to further economic development by encouraging the growth of productive private enterprise in member countries, particularly in the less developed areas." (IFC 2012, Art. 1)

Of course, the IFC is outright established as a corporation. It releases quarterly financial statements (IFC 2016) and also directly invests both IFC capital and capital from third-parties through its wholly-owned subsidiary, the IFC Asset Management Company, LLC (IFC 2019). As any corporate entity would, IFC's Investor Pitch Book boasts its triple A ratings, high liquidity, consistently growing assets, continued profitability, prudent approach to risk management, highly diversified portfolio, and low level of non-performing loans (IFC 2019). The IFC's operational structure has been recognized elsewhere as a "commercially-oriented business model" given that the institution "takes on the full commercial risks of its investments, accepts no government guarantees, generates profits, and regularly co-finances projects with commercial banks." (Wright 2012, p. 72) In fact, this commercial vocation manifested by the strong relationships it has forged with the private sector, including commercial banks, is considered to be a limiting factor in its willingness and ability "to promote those transparency and accountability standards that conflict with the interests of commercial banking institutions." (Wright 2012, p. 72)

The IFC is not alone in the limitations on promoting accountability and transparency out of a concern for performance, both at the institutional level and the individual staff level. An IEG analysis of the WBG Self-Evaluation Systems acknowledges traits of the institutional culture, which puts performance-and thus success and competition - ahead of learning and improvement, leaving staff wary of pointing out particular shortcomings in fear of failures tarnishing their professional reputation (IEG 2016).

The projects and programs run by MDBs are entrusted to professional management. A corporate-like institutional culture with an almost exclusive focus on skills considered essential to meet volume and profitability targets may also be fostered through recruitment practices. In calling for a wide geographical recruitment basis for officers and staff, the foundational agreements of many MDBs refer to the "paramount importance of securing the highest standards of efficiency and of technical competence" (IBRD 2012, Art. V Sec. 5(d); IDA 1960, Art. VI Sec. 5(d); IFC 2012, Art. IV Sec. 5(d); ADB 1965, Art. 34.6; AIIB 2015, Art. 30.3) with the exception of that of the AfDB, which also refers to "integrity" as an important consideration alongside efficiency and technical competence (AfDB 2016, Art. 37.5). How the in-house training of recruited staff is organized, what competences and skills are promoted are also important indicators of the institutional culture. The WB, for instance, proposed the Operational Core Curriculum (OCC), primarily targeting staff that will lead projects (called Task Team Leaders) as a course mostly through e-learning with a view to train staff on WB's own policies and procedures on lending, on improving problem-solving skills. This included "a behavioral module that treats team building as an integral part of project design and includes team-based role playing exercises" (IEG 2015, p. 21).

\section{Discourse}


The discourse used by MDBs both internally and in external communications carries traces of a corporate modus operandi. Stiglitz notes the importance of discourse in highlighting that "[a]lthough [the WB] is a development organization, it is organized as a bank, has many bank attributes - even to the extent of referring to the countries that provide funds as 'shareholders,' and to those who borrow funds as 'clients", (Stiglitz 2003, p. 123). The shareholder-client language transcends the WBG and extends to most MDBs. That jargon may be modified in some cases: for instance, the IDA external communications refer to "contributor countries" and "borrowing countries," which may reflect the fact that the organization is funded through donor replenishments and extends concessional loans to borrowers, which are not geared for profit-generation (IDA 2019).

The 'corporate' discourse at the WBG extends to the measurement of performance through the 'Corporate Scorecard' (analysed below) as well as the setting of 'corporate priorities' as well as 'corporate targets' for WBG operations. Likewise, at the $\mathrm{ADB}$, the performance measurement process is termed the "corporate results framework' and its latest assessment praise "the value of setting firm corporate targets" as a way of improving institutional performance (ADB 2017, p. 3) At the AfDB, 'The Results Measurement Framework' measuring performance is prepared by the Delivery, Performance Management And Results Department (AfDB 2017). AfDB's Website provides a snapshot of key facts and figures about the institution under the rubric of 'Corporate Information' (AfDB 2019).

\section{Evaluation of Performance}

MDBs increasingly measure annual performance through the use of indicators in line with the concept of effectiveness that has been at the height of the development cooperation and finance agenda. One example is the Corporate Scorecard (CSC), which was introduced in 2014 to rate the results and performance of WBG institutions. The Corporate Scorecard is based on three tiers: Tier I on Development Context, Tier II on Client Results, and Tier III on Performance. (WBG 2019a) The Corporate Scorecard focuses on three institutions, the WB (IBRD and IDA), IFC and MIGA as well as providing a WBG performance overview. In fact, besides Tier III on Performance, the indicators are not specific to WBG contributions to the development context or 'client' results. Tier III on Performance is assessed under five categories of indicators: Development Impact (including satisfactory outcome of operations, stakeholder feedback and client feedback), Strategic Context (including gender and climate aspects of financing), Operational Delivery for Clients (including commitments, disbursements, service quality and timeliness of delivery), Financial Sustainability and Efficiency (including revenues and their annual growth, loan exposure, budget anchor), and Talent Management (including staff engagement and diversity, inclusion and management effectiveness) (WBG 2019b). WB IEG was critical of the previous versions of the Corporate Scorecard, arguing that the indicators used "do not convey a sense of how the [WBG] is doing with respect to its targets" because "results are based on absolute numbers achieved, rather than percent of target, and operations in a few large countries are likely to skew the results." (IEG 
2017, p. 14) The scorecard was modified to reflect percentages and traffic lights indicate whether the performance meets pre-set targets.

Similar performance monitoring systems are used by other MDBs. ADB Corporate Results Framework proposal for 2019-2024, includes 60 indicators that are now aligned with the SDGs. The proposal retains the structure of the previous Corporate Results Framework set in two sections and four levels: first section on the general development outlook of the region to track the relevance of ADB's strategy (Level 1) and the second section on ADB performance in three different levels (Level 2 on quantified performance of ADB in completed operations, Level 3 on ADB performance in new and ongoing operations, Level 4 on ADB's organizational attributes in managing its operations) (ADB 2019a, b). ADB's indicators at Level 2 analyse quality as well as core sectoral results in strategic priority areas of energy, transport, water, finance, education, environment and regional cooperation (ADB 2013). In contrast to the WBG Scorecard, the ADB indicators on institutional performance evaluate overall satisfactory ratings given to sovereign and non-sovereign operations, project, strategies, based on a number of factors, including but not limited to returns and profitability as well as value-added co-financing and public-private partnerships (ADB 2019a, b). The new indicators include a range of sustainability and SDG-linked performance indicators as well. AfDB's current 'Results Measurement Framework' adopted in 2017 notes that it "needs to be supported by departmental incentives that are better aligned with the Bank's corporate priorities" and that the AfDB will update its Key Performance Indicators (KPIs) to reflect corporate priorities (AfDB 2017, p. 3).

The self-monitoring and evaluation of the IFC portfolio is undertaken in relation to three variables: Financial performance, development results, and environmental and social issues (IEG 2016). Financial performance is tracked through IFC's credit risk and profitability, development results are tracked by IFC's staff using indicators and compliance with environmental and social standards is monitored through a risk-management approach, using the environmental and social risk system. (IEG 2016) Sarfaty argues, for instance, that the IFC's explicit adoption of a human rights agenda is based on a market-based risk assessment logic: "translating international human rights norms for the business community by defining potential human rights violations as strategic risks, which may damage a company's reputation, threaten its profits, and lead to possible litigation." (Sarfaty 2012, p. 24).

\subsubsection{Relationships: Interlinked and Intertwined Markets}

Time and again, the experience of rights holders on the ground show that especially in project finance, the operations of MDBs are interlinked and intertwined with corporate actors from different sectors, including finance, construction, transport among others. As Meyersfeld and Kinley observe, given that the operations of financing institutions and corporate actors that undertake projects are intrinsically interlinked, "the role of banks matters enormously to the protection of human rights [because] [w]ithout investment and finance, corporate activity is blunt." (Meyersfeld and Kinley 2015, p. 193). Often, several MDBs cooperate with one another and with the private sector not only in co-financing projects but also in providing guarantees 
to the private capital invested. Increasingly, risk-sharing instruments such as blended finance that combine concessional finance with private resources, guarantees, insurance are being explored (G20-IFA WG 2017) When these co-financed projects lead to impacts on rights-holders, these impacts are not readily dissectible. A good example is the Bujagali Hydroelectric Powerplant Project in Uganda that was financed in a balance of credit and equity, with multilateral guarantees. (Erdem Türkelli 2020) In a snapshot, MDB funding in the form of loans was extended by the IFC, EIB, AfDB as well as a number of European national development finance institutions (DFIs) from France, Germany and the Netherlands. In addition, International Development Association (IDA), a part of the WB Group, provided a Partial Risk Guarantee on the commercial loans by private banks. (IFC/MIGA CAO 2011) Furthermore, more than $65 \%$ of the equity financing from the project sponsor company was covered by a Multilateral Investment Guarantee Agency (MIGA) guarantee. (MIGA 2008) Clearly, MDB commercial activities are interlinked and intertwined with private commercial activities in the practice of how development financing is delivered and put into use. It is particularly important to note that the involvement of MDBs, particularly important global or regional ones, work to crowd in investment from other concessional financiers such as national DFIs.

Cooperation with corporate actors is not just an inevitable result of the overlap of the operational activities and mandates but in fact discretionary. Many MDBs consider the private sector the quintessential driver of development and seek to "support the private sector gaps in finance, knowledge, and standards." (IFC 2011, pp. 1-2) The discourse of 'leveraging' financing by creating multiplier effects, such as converting every USD invested by shareholders into "2-5 dollars in new financing" is dominant at the MDBs in the post-2015 era. (AfDB et al. 2015, p. 2) The so-called 'scaling up of investment' means that MDBs often partner with corporate actors in co-investing in projects, where the institutions commit a portion of the total project cost, with private sector actors or borrower countries paying the remainder, and sharing the risk. MDBs have reportedly seen a four-fold increase in their direct private sector investments from 2000 to 2015 by capitalizing on these co-investing opportunities. (AfDB et al. 2015) In the post-2015 era, MDBs are looking to "mobilize private sector activity and investment in a more systematic fashion than on a project-by-project basis" (AfDB et al. 2015, p. 5) through assisting in evaluating and structuring investment projects, risk mitigation, co-investing with traditional and new types of investors, and launching new financial products (AfDB et al. 2017). Again, the enhanced engagement with the private sector blurs the functional lines between MDBs and private economic actors, strengthening the corporate business model espoused by MDBs.

\subsection{The Case for Limiting the Immunities of MDBs to Improve Rule of Law and Accountability to Rights-Holders}

Many commentators have suggested that MDBs need to strengthen their independent review mechanisms to provide accountability to affected populations in order to 
curb litigations. $^{22}$ (Gulati 2019; Bradlow 2019; Bradlow Forthcoming). MDB compliance with their own regulatory frameworks is an area in which MDBs still need to do better (Rich 2019) but is far from enough. What is needed is external accountability, without which patterns of structural global inequalities and hegemony is reinforced and reproduced (Tan 2019). As Tan poignantly reminds in the case of the Bretton Woods Institutions (BWI),

Locating the BWIs' human rights obligations within a wider framework of public and private international law and incorporating human rights concerns into domestic legal processes may assist us in going beyond a conceptual analysis of human rights violations and towards establishing an operational framework for achieving BWI accountability. (Tan 2019, p. 14)

As Alvarez points out, the accountability to shareholding states (through answering to their executive or legislative bodies) is fundamentally different than "mak[ing] these institutions (or their executive boards or distinct major contributors to their respective budgets) accountable to the poor or indigenous peoples affected by either the Bank's infrastructure projects or the macroeconomic conditions imposed under the IMF's structural adjustment loans." (Alvarez 2016, p. 15) Of course, the process requires a move away from mainstream legal classifications under public international law as well as a deeper understanding of what accountability should entail if it is to have any meaning with respect to how rights-holders experience the everyday impacts of MDB activities and decisions.

The ability of MDBs to exist behind a delegate veil despite their manifest autonomy from shareholding states and the corporate-like nature of many of their activities is problematic from the perspective of rule of law and accountability to rights-holders. Any comprehensive formulation of rule of law relying on legally promulgated rules at the domestic or the international level should cover rules in the legal corpus pertaining to human rights protections for affected individuals or groups, whether these rules are adopted at the domestic level through constitutional means or other legislation, or internationally through treaties or customary international law, thereby creating international obligations. ${ }^{23}$ What may be indispensable and even inevitable is to lift the delegate veil under which MDBs habitually operate so that they "no longer hide under a cloak of immunity for the wrongs they commit acting as commercial players in the marketplace" (Trundle 2019).

From the perspective of the rights-holder, the social, economic and environmental impacts arising from collaborations of functionally common but legally distinct entities such as economic corporations and MDBs are not distinguishable. In such cases, the fact that one (the economic corporation) can theoretically be held to

\footnotetext{
22 One such proposal is to create a Super-IAM, a collaborative IAM to serve all MDBs that can deal with instances of non-compliance, buttressed by an assistance fund for affected persons (Bradlow 2020).

${ }^{23}$ Even in dualist systems, the need to incorporate an international treaty into domestic law for it to be invoked in domestic judicial mechanisms (thus, in the processes for eliciting legal responsibility) does not negate the obligation and the compliance requirements brought about by that obligation.
} 
account in states where it operates or is headquartered for the same impacts ${ }^{24}$ while the other (MDB) remains immune creates clear gaps in the respect for rule of law and human rights protections. From a moral standpoint as well, the legal categorization of a particular actor should be inconsequential when rights-holders whose rights are adversely affected seek access to remedies.

In Jam et al. v. the IFC, an amici curiae brief from Former Secretaries of State and Secretaries of the Treasury claimed that " $[\mathrm{t}]$ he international community agreed from the outset that international organizations like IFC would be answerable to their member countries alone, acting through their representatives on their Boards, and free from local control". (Former Secretaries of State and Secretaries of the Treasury 2018, p. 11) The SCOTUS responded by noting that the "rules might themselves change over time in light of developments in the law". (SCOTUS 2019, p. 2) In that light, it may be high time to consider changing the rules by lifting the delegate veil in order to be able to hold MDBs accountable in domestic settings.

The application of external accountability to all MDBs regardless of who their shareholders (member states) are, would also mean a level playing field and alleviate fears that more stringent standards adopted by a given MDB would allow another less scrupulous one to poach clients and lead to an even more detrimental outcome in terms of human rights. ${ }^{25}$ The WB or any other MDB recognizing that it owes duties to rights-holders when it decides on a policy or instigates a project will not render it less of an international organization or call into question its legal personality. It will, on the contrary, affirm that as a powerful economic actor on the world stage, this actor not only enjoys rights but also has corresponding obligations. As the SCOTUS noted, the routine ascription of immunities to an IO does not mean that immunity is or should be absolute. It also should not mean that such an actor cannot be held to basic standards of accountability by being asked to incorporate human rights respect and protection norms in its regulatory structures to prevent and mitigate adverse impacts on individuals or societies or to be held to account externally (either at the domestic or international levels) when it acts in breach of the publicly proclaimed laws and internationally proclaimed obligations of the states in which or from where it operates.

Open Access This article is licensed under a Creative Commons Attribution 4.0 International License, which permits use, sharing, adaptation, distribution and reproduction in any medium or format, as long as you give appropriate credit to the original author(s) and the source, provide a link to the Creative Commons licence, and indicate if changes were made. The images or other third party material in this article are included in the article's Creative Commons licence, unless indicated otherwise in a credit line to the material. If material is not included in the article's Creative Commons licence and your intended use is not permitted by statutory regulation or exceeds the permitted use, you will need to obtain permission directly from the copyright holder. To view a copy of this licence, visit http://creativecommons.org/licen ses/by/4.0/.

\footnotetext{
${ }^{24}$ Assuming that these states are willing and able to hold them to account either under domestic law or through legislation with extraterritorial effects, which is a question dealt with extensively in the Business and Human Rights Domain.

${ }^{25}$ Such fears were clearly voiced during the World Bank's update of its safeguards to call for milder regulation.
} 


\section{References}

African Development Bank (AfDB) (2016) Agreement Establishing the AfDB, 2016 edn

African Development Bank (AfDB) (2017) The bank group results measurement framework 2016-2025: delivering the high $5 \mathrm{~s}$, increasing the bank's impact on development, April 2017. https://www. afdb.org/fileadmin/uploads/afdb/Documents/Policy-Documents/Final_-_RMF_-_Rev.2_Final _.pdf. Accessed 24 Nov 2019

African Development Bank (AfDB) (2019) Corporate information. https://www.afdb.org/en/about-us/ corporate-information/. Accessed 24 Nov 2019

African Development Bank (AfDB) et al (2015) From billions to trillions: MDB contributions to financing for development

African Development Bank (AfDB) et al (2017) Mobilization of private finance by multilateral development banks: 2016 joint report

Alvarez JE (2016) International organizations and the rule of law. N Z J Public Int Law 14(1):3-46

Asian Development Bank (ADB) (1965) Agreement establishing the Asian Development Bank (ADB Charter)

Asian Development Bank (ADB) (2013) Guidelines for the use of ADB's results framework indicators for core sector outputs and outcomes

Asian Development Bank (ADB) (2017) 2016 Development effectiveness review

Asian Development Bank (ADB) (2019a) Policy paper: ADB corporate results framework, 2019-2024. https://www.adb.org/sites/default/files/institutional-document/504656/policy-paper-adb-resultsframework-2019-2024-circulation-22-august.pdf. Accessed 24 Nov 2019

Asian Development Bank (ADB) (2019b) Results framework indicator definitions. https://www.adb.org/ sites/default/files/institutional-document/33902/rfw-indicator-definitions-mar2019.pdf. Accessed 21 Nov 2019

Asian Infrastructure Investment Bank (AIIB) (2015) Articles of agreement of the Asian Infrastructure Investment Bank

Awori S et al (2018) A feminist approach to the binding instrument on transnational corporations and other business enterprises. Bus Hum Rights J 3(2):285-290

Baimu E, Panou A (2012) Responsibility of and the World Bank Inspection Panel: parallel tracks unlikely to international organizations converge? In: Cissé $\mathrm{H}$ et al (eds) International financial institutions and global legal governance, the World Bank legal review, vol 3. World Bank, Washington D.C., pp 147-172

Bank Information Center (BIC) (2013) Human rights and the World Bank: case studies from IDA countries. BIC, Washington D.C

Barnebeck A et al (2006) US politics and World Bank IDA-lending. J Dev Stud 42(5):772-794

Barros AS (2019) Governance as responsibility: member states as human rights protectors in international financial institutions. Cambridge University Press, Cambridge

Benvenisti E (2014) The Law of Global Governance. Brill/Nijhoff, Leiden

Bilchitz D (2016) The necessity for a business and human rights treaty. Bus Hum Rights J 1(2):203-227

Bradlow DD (1996) The World Bank, the IMF, and human rights. Transnatl Law Contemp Probl $6(1): 47-90$

Bradlow DD (2010) International Law and the Operations of the International Financial Institutions. In: Bradlow DD, Hunter DB (eds) International Financial Institutions and International Law. Wolters Kluwer, Alphen aan den Rijn, pp 1-30

Bradlow DD (2011) The reform of the governance of the IFIs: a critical assessment. In: Cissé $\mathrm{H}$ et al (eds) International financial institutions and global legal governance, The world bank legal review, vol 3. The World Bank

Bradlow DD (2016) Brief of Amicus Curiae Professor Daniel Bradlow In Support of Plaintiffs-Appellants, No. 16-7051, the United States Court of Appeals for the District of Columbia

Bradlow DD (2017) Using a shield as a sword: are international organizations abusing their immunity? Temple Int Comp Law J 31(1):45-67

Bradlo DD (2019) Multilaterals must earn the right to limited immunity. Financial Times. 28 March 2019, https://www.ft.com/content/2512aa84-515d-11e9-9c76-bf4a0ce37d49. Accessed 1 March 2020

Bradlow DD Multilateral development banks, their member states and public accountability: a proposal. Indian J Int Econ Law. Available at SSRN: https://ssrn.com/abstract=3404157 (forthcoming) 
Cassese S (2005) Administrative law without the state? The challenge of global regulation. N Y Univ J Int Law Polit 37(4):663-694

Cissé H (2011) Should the political prohibition in charters of international financial institutions be revisited? The case of the World Bank. In: Cissé $\mathrm{H}$ et al (eds) The World Bank legal review: law, international financial institutions and global legal governance, vol 3. World Bank, Washington D.C., pp 59-92

Coleman JS (1974) Power and the structure of society. W.W. Norton and Company, New York

Coleman JS (1990) The foundations of social theory. The Belknap Press of Harvard University Press, Cambridge

Coleman JS (1992) The vision of foundations of social theory. Anal Kritik 14:117-128

Collins R, White ND (eds) (2011) International organizations and the idea of autonomy: institutional independence in the international legal order. Routledge, New York

Daniel C et al (eds) (2016) Glass half full? The state of accountability in development finance. SOMO, Amsterdam

Dann P (2017) The global administrative law of development cooperation. In: Cassese S (ed) Research handbook on global administrative law. Edward Elgar, Cheltham, pp 415-435

Dann P, Riegner M (2019) The world bank's environmental and social safeguards and the evolution of global order. Leiden J Int Law 32(3):537-559. https://doi.org/10.1017/S0922156519000293

Daugirdas K (2013) Congress underestimated: the case of the world bank. Am J Int Law 107(3):517-562

De Feyter K (2002) International financial institutions and human rights-law and practice. Institute of Development Policy and Management, University of Antwerp, Discussion Paper

De Schutter O et al (2012) Commentary to the Maastricht principles on extraterritorial obligations of states in the area of economic, social and cultural rights. Hum Rights Q 34(4):1084-1169

Dreher et al (2009) Development aid and international politics: does membership on the UN Security Council influence World Bank decisions? J Dev Econ 88(1):1-18

Earth Rights International (2019) Budha Ismail Jam, et al v. IFC: an Indian fishing community takes on the World Bank. https://earthrights.org/case/budha-ismail-jam-etal-v-ifc/. Accessed 18 Oct 2019

Einhorn J (2001) The World Bank's Mission Creep. Foreign Affairs 80(5). September/October 2001, https://www.foreignaffairs.com/articles/2001-09-01/world-banks-mission-creep. Accessed 18 Oct 2019

Erdem Türkelli G (2020) Children's rights and business: governing obligations and responsibility. Cambridge University Press, Cambridge

Former Secretaries of State and Secretaries of the Treasury (2018) Brief of Amici Curiae Former Secretaries pf State and Secretaries of The Treasury in Support of Respondent International Finance Corporation-BUDHA ISMAIL JAM et al. v. the IFC, September 17, 2018

G20-IFA WG (2017) Principles of MDBs' strategy for crowding-in Private Sector Finance for growth and sustainable development

Gulati R (2019)The immunities of international organisations: the end of impunity?. Opinio Juris, 1 March 2019. http://opiniojuris.org/2019/03/01/the-immunities-of-international-organisations-theend-of-impunity/. Accessed 1 March 2020

Hessen R (2007) Corporations. In: Henderson DR (ed) The Concise Encyclopedia of Economics, 2nd edn/online edn, 2007. http://www.econlib.org/library/CEE.html. Accessed 18 Oct 2019

IFC (2018) Brief for Respondent, BUDHA ISMAIL JAM, ET AL., v. INTERNATIONAL FINANCE CORPORATION, On Writ of Certiorari to the United States Court of Appeals for the District of Columbia Circuit, 10 September 2018

IFC (2019) Financial Statements. http://www.ifc.org/wps/wcm/connect/corp_ext_content/ifc_external_ corporate_site/about+ifc_new/ifc+governance/investor+relations/financial+statements. Accessed 25 Nov 2019

IFC/MIGA CAO (2011) Ombudsman Assessment Report, Fifth Complaint (Bujagali Energy-05) Regarding the Bujagali Energy Ltd. Project (IFC \#24408 \& MIGA \#6732)

IFC/MIGA CAO (2013) CAO Operational Guidelines

Independent Evaluation Group (IEG) (2012) The matrix system at work: an evaluation of the world bank's organizational effectiveness

Independent Evaluation Group (IEG) (2015) Learning and results in world bank operations: toward a new learning strategy evaluation 2. World Bank, Washington

Independent Evaluation Group (IEG) (2016) Behind the mirror: a report on the self-evaluation systems of the World Bank Group. World Bank, Washington 
Independent Evaluation Group (IEG) (2017) Results and performance of the World Bank Group 2016: an independent evaluation. World Bank, Washington

International Bank of Reconstruction and Development (IBRD) Articles of Agreement (as amended effective June 27, 2012)

International Development Association (IDA) (1960) Articles of Agreement (as Adopted September 24, 1960)

International Development Association (IDA) (2019) Who we are. http://ida.worldbank.org/about/whowe-are. Accessed 25 Nov 2019

International Finance Corporation (IFC) (2011) International finance institutions and development through the private sector: a joint report of 31 multilateral and bilateral development finance institutions

International Finance Corporation (IFC) (2012) Articles of agreement (as amended effective June 27, 2012)

International Finance Corporation (IFC) (2016) Annual information statement-financial year 2016

International Finance Corporation (IFC) (2019) Investing for impact, March 2019. https://www.ifc.org/ wps/wcm/connect/e3f12da4-4e58-43c9-9ba2-a90714aedd8f/FY19+Investor+Presentation_03062 019.pdf?MOD=AJPERES. Accessed 18 Oct 2019

Investopedia (2019) Corporation. http://www.investopedia.com/terms/c/corporation.asp\#ixzz4lh781K8d. Accessed 25 Sept 2019

IUN General Assembly (UNGA) (2015) Report of the Philip Alston (Special Rapporteur on Extreme Poverty and Human Rights), Rep. on the Human Rights Policy of the World Bank, U.N. Doc. A/70/274 (Aug. 4, 2015). http://www.un.org/ga/search/view_doc.asp?symbol=A/70/274

Jokubauskaite G (2020) The concept of affectedness in international development. World Dev 126:1-11

Kersting E, Kilby C (2016) Do domestic politics shape U.S. influence in the World Bank? AidData, Working Paper 28, July 2016

Khan I (2016) Shifting the paradigm: rule of law and the 2030 agenda for sustainable development. In: Fariello F et al (eds) Financing and implementing the post-2015 development agenda: the role of law and justice systems, The World Bank Legal Review, vol 7. World Bank, Washington D.C., pp $221-253$

Kilby C (2006) Donor influence in multilateral development banks: The case of the Asian Development Bank. Review of International Organizations 1(2):173-195

Kilby C (2009) The political economy of conditionality: a empirical analysis of World Bank loan disbursements. J Dev Econ 89(1):51-61

Kilby C (2013) An empirical assessment of informal influence in the World Bank. Econ Dev Cult Change 61(2):431-464

Kingsbury B (2011) Global administrative law in the institutional practice of global regulatory governance. In: Cissé $\mathrm{H}$ et al (eds) The World Bank legal review: law, international financial institutions and global legal governance, vol 3. World Bank, Washington D.C., pp 3-33

Kingsbury B et al (2005) The emergence of global administrative law. Law Contemp Probl 68:15-62

Klabbers J (2015) The EJIL foreword: the transformation of international organizations law. EJIL 26(1):9-82

Klabbers J (2017a) International law, 2nd edn. Cambridge University Press, Cambridge

Klabbers J (2017b) Transforming institutions: autonomous international organisations in institutional theory. Camb Int Law J 6(2):105-121

Lawrence RZ (2008) International organisations: the challenge of aligning mission, means and legitimacy. World Econ 31(11):1455-1470

López Latorre A (2020) In defence of direct obligations for businesses under international human rights law. Bus Hum Rights J, 1-28

Martha RSJ (2011) International financial institutions and claims of private parties: immunity obliges. In: Cissé $\mathrm{H}$ et al (eds) International financial institutions and global legal governance, the World Bank legal review, vol 3. World Bank, Washington D.C., pp 93-131

McBeth A (2009) International economic actors and human rights. Routledge, Oxon

McInerney-Lankford S (2010) International financial institutions and human rights: select perspectives on legal obligations. In: Bradlow DD, Hunter DB (eds) International financial institutions and international law. Wolters Kluwer, Alphen aan den Rijn, pp 262-264

Meyersfeld B, Kinley D (2015) Banks and human rights: a South African experiment. SUR Int J Hum Rights 12(22):189-205

MIGA (2008) Power brief-MIGA: fortifying power investments, April 2008 
Natenson M (2015) The World Bank Group's human rights obligations under the United Nations guiding principles on business and human rights. Berkeley J Int Law 33(2):489-525

New Development Bank (NDB) (2015) Agreement on the new development bank

Palacio A (2006) The way forward: human rights and the world bank, WB, October 2006. http://go.world bank.org/RR8FOU4RG0. Accessed 25 Nov 2019

Pilon R (1979) Book review: in defense of the corporation. Emory Law J 28(2):405-428

Provost C (2017) Farmers sue World Bank lending arm over alleged violence in Honduras. The Guardian, 8 March 2017. https://www.theguardian.com/global-development/2017/mar/08/farmers-sueworld-bank-lending-arm-ifc-over-alleged-violence-in-honduras. Accessed 23 Sept 2019

Rich B (2002) The World Bank under James Wolfensohn. In: Pincus JR, Winters JA (eds) Reinventing the World Bank. Cornell University Press, Ithaca, pp 27-33

Rich B (2019) The World Bank and the environment: A legacy of negligence, reform, and dysfunction. Bretton Woods Project, Bretton Woods at 75: a series of critical essays. Bretton Woods Project, London, pp 15-18

Sarfaty GA (2009) Why culture matters in international institutions: the marginality of human rights at the World Bank. Am J Int Law 103:647-683

Sarfaty GA (2012) Values in translation: human rights and the culture of the World Bank. Stanford University Press, Stanford

Supreme Court of the United States (SCOTUS) (2018) Budha Ismail Jam et al. v. International Finance Corp., 2018 Petition for A Writ of Certiorari

Shihata IEI (1996) The World Bank's protection and promotion of children's rights. The International Journal of Children's Rights 4(4):383-406

Skogly SI (2003) The human rights obligations of the World Bank and IMF. In: Van Genugten W et al (eds) World Bank, IMF and human rights. Wolf Legal Publishers, Nijmegen, pp 45-78

Stiglitz JE (2003) Democratizing the International Monetary Fund and the World Bank: governance and accountability. Governance 16(1):111-139

Supreme Court of Canada (2020) Nevsun Resources Ltd. v. Araya, 2020 SCC 5

Supreme Court of the United States (SCOTUS) (2019) Budha Ismail Jam et al. v. International Finance Corp., 586 U.S. (2019)

Tan C (2019) Human rights and the Bretton Woods Institutions: Moving beyond institutional remedies. Bretton Woods Project, Bretton Woods at 75: a series of critical essays. Bretton Woods Project, London, pp 12-14

The World Bank Treasury (n.d.) Everything you always wanted to know about the World Bank. https:// www.iffim.org/library/publications/factsheets/the-world-bank/. Accessed 25 Nov 2019

Trundle C (2019) A revised take on the immunity of international organizations in U.S. Courts: Jam v. International Finance Corporation, Minnesota Journal of International Law (MJIL) Blog, 29 March 2019. http://minnjil.org/a-revised-take-on-the-immunity-of-international-organizations-in-u-scourts-jam-v-international-finance-corporation/. Accessed 1 March 2020

Van Genugten W (2015) The World Bank Group, the IMF and human rights. A contextualised way Forward. Intersentia, Cambridge

Veldman J, Willmott H (2013) What is the corporation and why does it matter?. M@n@gement 2013/5 16:605-620

Von Bogdandy A et al (2010) Developing the publicness of public international law: towards a legal framework for global governance activities. In: Von Bogdandy A et al (eds) The exercise of public authority by international institutions. Springer, Heidelberg

Woods N (2003) Unelected government: making the IMF and the World Bank more accountable. https ://www.brookings.edu/articles/unelected-government-making-the-imf-and-the-world-bank-moreaccountable/. Accessed 25 Nov 2019

World Bank (WB) (2015) The World Bank environmental and social framework

World Bank (WB) (2020) Bank Directive: Environmental and Social Directive for Investment Project Financing, OPS5.03-DIR.113, 28 Jan 2020

World Bank Group (WBG) (2019a) About the corporate scorecards. https://scorecard.worldbank.org. Accessed 25 Nov 2019

World Bank Group (WBG) (2019b) Corporate scorecards tier 3. https://scorecard.worldbank.org/tier3 -performance. Accessed 25 November 2019

Wright C (2012) Global banks, the environment, and human rights: the impact of the equator principles on lending policies and practices. Glob Environ Polit 12(1):56-77 
United Nations General Assembly (UNGA) (2019) Report of the Independent Expert on the effects of foreign debt and other related international financial obligations of States on the full enjoyment of all human rights, particularly economic, social and cultural rights: Responsibility for complicity of IFIs in human rights violations in the context of retrogressive economic reforms, A/74/178.

Zimmermann SS, Fariello FA Jr (2012) Coordinating the fight against fraud and corruption: agreement on cross-debarment among multilateral development banks. In: Cissé $\mathrm{H}$ et al (eds) International financial institutions and global legal governance, the World Bank legal review, vol 3. World Bank, Washington D.C., pp 189-204

Publisher's Note Springer Nature remains neutral with regard to jurisdictional claims in published maps and institutional affiliations.

\section{Affiliations}

\section{Gamze Erdem Türkelli ${ }^{1}$}

Gamze Erdem Türkelli

gamze.erdemturkelli@uantwerpen.be

1 Law and Development Research Group, Post-Doctoral Fellow Fundamental Research, Research Foundation Flanders (FWO) File Number: 12Q1719N, University of Antwerp Faculty of Law, Venusstraat 23 V.104, 2000 Antwerp, Belgium 